Jurnal Keperawatan Silampari

Volume 4, Nomor 2, Juni 2021

e-ISSN: 2581-1975

p-ISSN: 2597-7482

DOI: https://doi.org/10.31539/jks.v4i2.1916

\title{
GAYA KEPEMIMPINAN DEMOKRATIS DIREKTUR RUMAH SAKIT TERHADAP KEDISIPLINAN KARYAWAN
}

\author{
Fadilla Delima Sandi ${ }^{1}$, Nyoman Anita Damayanti ${ }^{2}$ \\ Universitas Airlangga ${ }^{1,2}$ \\ fadilladelima@gmail.com ${ }^{1}$
}

\begin{abstract}
ABSTRAK
Penelitian ini bertujuan untuk mengetahui pengaruh gaya kepemimpinan demokratis direktur rumah sakit terhadap kedisiplinan karyawan RSU DR Moedjito Dwidjosiswojo. Metode penelitian ini menggunakan metode survei dilakukan dengan pengumpulan data melalui angket (questionnaire). Hasil penelitian menunjukkan bahwa gaya kepemimpinan di RSU dr Moedjito Dwidjosiswojo ada 3, otokritas nilai 6 dengan SD 0, demokratis nlai 21 dengan SD 5 dan bebas nilai 1 dengan SD 1. Simpulan, gaya kepemimpinan demokratis direktur RSU dr Moedjito Dwidjosiswojo mempengaruhi kedisplinan karyawan dengan terbukti nihilnya karyawan tidak disiplin berdasarkan jam datang kerja yang telah ditentukan.
\end{abstract}

Kata Kunci: Gaya Kepemimpinan, Kedisiplinan Karyawan

\section{ABSTRACT}

This study aims to determine the effect of the democratic leadership style of the hospital director on the discipline of the employees of RSU DR Moedjito Dwidjosiswojo. This research method uses a survey method carried out by collecting data through a questionnaire (questionnaire). The results showed three leadership styles at Dr. Moedjito Dwidjosiswojo General Hospital, 6 with SD 0, democracy with 21 points with $5 \mathrm{SD}$, and accessible 1 with 1 SD. In conclusion, Dr. Moedjito Dwidjosiswojo's director's democratic leadership style influenced employee discipline with no evidence. Undisciplined employees based on predetermined work hours.

Keywords: Leadership Style, Employee Discipline

\section{PENDAHULUAN}

Rumah sakit adalah salah satu sarana pelayanan kesehatan baik individu maupun masyarakat dan merupakan bagian terdepan dalam memberikan pelayanan kepada individu atau masyarakat diperlukan perawat yang memberikan pelayanan keperawatan, Perawat menjadi salah satu bagian dalam pemberian pelayanan kesehatan di rumah sakit. Sistem kesehatan di rumah sakit meliputi pelayanan medik rehabilitasi medik dan pelayanan keperawatan. Hal ini berarti bahwa pelayanan pada klien di rumah sakit tidak terlepas dari pelayanan keperawatan (Tilman et al., 2019).

Gaya kepemimpinan dapat mempengaruhi kepuasaan kerja perawat karena melalui sebuah gaya kepemimpinan seorang pemimpin atau kepala ruangan dapat memperlakukan bawahan atau perawat pelaksana untuk bekerja dengan hati lebih termotivasi sehinggah perawat merasa lebih puas dalam bekerja. Ada berberapa tipe 
gaya kepemimpinan yaitu, gaya kepemimpinan otoriter, direktif, suportif, dan partisipatif (Marques et al., 2021).

Gaya kepemimpinan yang diterapkan dalam oragnisasi dapat membantu untuk terciptanya keefektifan kerja yang positif bagi anggota. Dengan adanya gaya kepemimpinan dengan situasi dan kondisi suatu organisasi maka anggota akan memberikan semangat yang tinggi dalam menjalankan tugas serta kewajiban dalam mencapai tujuan bersama. Selain itu, gaya kepemimpinan juga bisa memberikan dampak negatif, salah satunya adalah menurunnya kinerja anggota (Rumaisha et al., 2019).

Baik buruknya kinerja seseorang dipengaruhi oleh berbagai faktor salah satunya adalah faktor organisasi, gaya kepemimpinan dan karakteristik pemimpin. Gaya kepemimpinan dimana pemimpin menganggap dirinya sebagai bagian dari kelompok dengan mendengarkan saran dari bawahannya dan karakteristik pemimpin yang mampu bekerjasama dengan bawahannya, percaya diri terhadap pengetahuan yang dimilikinya juga mempunyai ide baru dalam peningkatan pelayanan kesehatan dapat meningkatkan kinerja perawat (Rumaisha et al., 2019).

Rumah sakit merupakan sebuah organisasi yang besar dan untuk menjalankan kepemimpinan di organisasi yang besar diperlukan pemikiran dan tindakan yang besar pula serta kebijakan dan keputusan yang matang. Bukanlah perkara mudah menjalankan hal tersebut. Diperlukan keterampilan dan kemampuan yang luar biasa dan teori-teori serta metode dalam melaksanakan kepemimpinan yang baik dari organisasi tersebut.

Sebuah Rumah Sakit harus dipimpin oleh seorang Kepala tenaga medis yang mempunyai kemampuan dan keahlian di bidang perumahsakitan (UU No. 44 pelayanan kesehatan masyarakat harus memiliki kompetensi manajemen kesehatan masyarakat yang dibutuhkan (UU No. 36 Tahun : Pasal 33). Kompetensi yang dimaksud dalam undang-undang ini pada hakekatnya tidak saja kompetensi manajerial, melainkan juga termasuk kemampuan untuk memimpin organisasi rumah sakit, yang kompleks dan kompetitif. Sehingga penelitian ini berfokus pada gaya kepemimpinan demokratis direktur terhadap kedisiplinan karyawan.

\section{METODE PENELITIAN}

Data terkait survei ini diambil dari dokumen manajemen RSU dr Moedjito Dwidjosiswojo dan pengambilan data primer yaitu dengan membagikan kuesioner kepada responden. Kuesioner dibagikan kepada karyawan yang terpilih dengan cara acak. Sebelum pengisian kuesioner, responden diberitahu cara pengisian. Metode survei survei dengan tekhnik pengambilan sampel yaitu simple random sampling, dengan 27 sampel dari $20 \%$ total populasi yang berjumlah 132 karyawan. Dan metode pengumpulan data melalui angket (questionnaire). Data di olah menggunakan uji regresi linier. Dan skala pengukuran menggunakan skala likert. yang dimana jawaban dari setiap pertanyaan ditentukan berdasarkan urutan pola jawaban 1, 2, 3, 4, 5 dengan asumsi bahwa:

$\begin{array}{lr}\text { Jawaban Sangat Setuju } & \text { diberi skor } 5 \\ \text { Jawaban Setuju } & \text { diberi skor } 4 \\ \text { Jawaban Netral } & \text { diberi skor 3 } \\ \text { Jawaban Tidak Setuju } & \text { diberi skor 2 } \\ \text { Jawaban Sangat Tidak Setuju } & \text { diberi skor 1 }\end{array}$




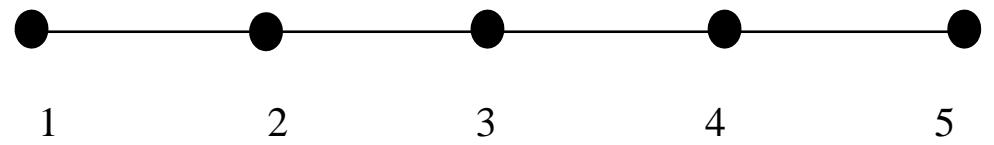

Dengan keterangan :

4.6-5.0 = Otokratis/Demokratis/Laissez Faire

$4.0-4.5=$ Otokratis/Demokratis/Laissez Faire

$3.6-4.0=$ Sedikit Otokratis/Demokratis/Laissez Faire

$2.0-3.5=$ Tidak Otokratis/Demokratis/Laissez Faire

$1.0-1.9=$ Tidak Otokratis/Demokratis/Laissez Faire

Kategori suvei disiplin

Tidak Disiplin : Kedatangan jam $>07.10 \mathrm{WIB}$

Disiplin : Kedatangan jam 07.00-07.10 WIB

Sangat Disiplin : Kedatangan jam $<07.00$ WIB

\section{HASIL PENELITIAN}

Survei dilakukan di RSU dr Moedjito Dwidjosiswojo. Karyawan yang diteliti sebanyak 27 orang. Dibedakan berdasarkan masa kerja yaitu $<1$ tahun, 1-3 tahun dan $>3$ tahun.

Tabel. 1

Rekapitulasi Gaya Kepemimpinan Terhadap Kedisiplinan Jam Datang Kerja Responden

\begin{tabular}{lcccccc}
\hline & & & \multicolumn{4}{c}{ Lama Masa Kerja } \\
\hline \multicolumn{1}{c}{ Gaya Kepemimpinan } & TD & D & SD & $<1$ th & $1-3$ th & $>3$ th \\
Otokritas & 0 & 6 & 0 & 1 & 1 & 4 \\
Demokratis & 0 & 21 & 5 & 7 & 3 & 14 \\
Bebas & 0 & 1 & 1 & 1 & 0 & 1 \\
\hline
\end{tabular}

Berdasarkan tabel 1 menunjukkan bahwa mayoritas gaya kepemimpinan di RSU dr Moedjito Dwidjosiswojo adalah gaya kepemimpinan demokratis dengan lama masa kerja $>3$ tahun.

\section{PEMBAHASAN}

Berdasarkan tabel 1 menunjukkan bahwa karyawan RSU dr Medjito Dwidjosiswojo lebih banyak menilai bahwa direktur rs memiliki gaya kepemimpinan demokratis dan responden yang memilih gaya kepemimpinan demokratis memiliki tingkat kedisiplinan yang tinggi. Mayoritas responden yang meilih gaya kepemimpinan demokratis dengan lama masa kerja lebih dari tiga tahun. Namun dalam survei yang dilakukan bahwa responden juga merasakan direktur menganut gaya kepemimpinan otokritas dan responden yang memilihnya yaitu pada lama masa kerja lebih dari tiga tahun.

Kepemimpinan sebagai suatu bentuk persuasi, suatu seni pembinaan kelompok orang-orangtertentu, biasanya melalui 'human relations' dan motivasi yang tepat, sehingga tanpaadanya rasa takut mereka mau bekerja sama dan membanting tulang memahami dan mencapai segala apa yang menjadi tujuan-tujuan organisasi (Mugianti, 2016). 
Hasil penelitian Marques et al., (2021) didapatkan sebagian besar responden menilai gaya kepemimpinan kepala ruangan dalam kategori baik yaitu sebanyak 18 orang $(46,2 \%)$, sebagian besar responden memiliki kepuasan kerja perawat dalam kategori puas yaitu sebanyak 26 orang $(66,7 \%)$. Hasil uji Chi-square membuktikan bahwa ada pengaruh yang singnifikan antara gaya kepemimpinan kepala ruangan terhadap kepuasan kerja perawat dengan nilai $p$ value $=0,003(\alpha<0,05)$.

Marques et al., (2021) mejelaskan bahwa gaya kepemimpinan berpengaruh terhadap kepuasan kerja perawat gaya kepemimpinan sangat efektif mempengaruhi kepuasan kerja perawat karena melalui gaya kepemimpinan seorang pemimpin atau kepala ruangan dapat memperlakukan bawahan atau pelaksana untuk bekerja dengan hati dan lebih termotivasi sehingga perawat merasa lebih puas dalam melakukan tindakan.Sedangkan perawat dengan gaya kepemimpinan kepala ruangan dalam kategori cukup dan kurang memiliki kepuasan kerja perawat yang tidak puas. Hal ini menunjukkan gaya kepemimpinan kepala ruangan mempengaruhi kepuasan kerja yang dimiliki perawat. Semakin baik gaya kepemimpinan kepala ruangan maka semakin puas juga perawat bekerja begitu pula sebaliknya.

Hasil penelitian Rumaisha et al., (2019) menunjukkan bahwa terdapat hubungan antara gaya kepemimpinan dengan kinerja perawat di puskesmas Teraken dengan nilai koefisien positif, sehingga gaya kepemimpinan demokratis memberikan peningkatan kinerja pada perawat Puskesmas Teraken Kecamatan Teraken. Hasil penelitian Amalia et al., (2016) menyatakan bahwa Direktur RSUD Sayang Rakyat menjalankan gaya kepemimpinan yang demokratis.

Gaya kepemimpinan demokratis merupakan gaya kepemimpinan yang bersifat ramah dalam komunikasi, selalu bersedia menolong dan melayani bawahannya dengan memberikan nasihat, memberi petunjuk pada saat dibutuhkan, menempatkan manusia sebagai faktor utama dan terpenting dalam setiap kelompok dengan cara memberi kesempatan bagi anggota kelompok untuk berpartisipasi dalam setiap kegiatan. Selain itu, setiap anggota dibantu dalam mengembangkan sikap dan kemampuan memimpin. Sehingga dalam perkembangan karirnya, setiap anggota memiliki kesempatan menduduki jabatan sebagai pemimpin (Rumaisha et al., 2019). Hal ini sejalan dengan penelitian Kurniawan (2018) yang menjelaskan bahwa gaya kepemimpinan demokratis memiliki pengaruh yang signifikan dan positif terhadap kinerja karyawan.

Semakin baik gaya kepemimpinan demokratis seorang pimpinan maka semakin baik loyalitas karyawan, dimana pimpinan yang mempunyai gaya kepemimpinan demokratis senantiasa akan memberikan segala upaya yang terbaik untuk perusahaaan dan bawahannya. Selain gaya kepemimpinan demokratis, prestasi kerjapun dapat mempengaruhi loyalitas karyawan (Pratama \& Zuriana, 2018).

Menurut Gannika \& Buanasasi (2019) kemampuan dan pengalaman kerja perawat tinggi dalam memberikan pelayanan keperawatan kepada pasien, meskipun persentase terbanyak adalah gaya kepemimpinan lemah yang artinya pemimpin masih kurang memberikan tindakan atau kemampuan dalam mengarahkan dan mempengaruhi aktivitas yang berkaitan dengan tugas tanggung jawabnya. Akan tetapi hal ini tidak mempengaruhi kinerja perawat menjadi menurun karena perawat sadar akan tanggung jawabnya dalam memberikan pelayanan perawatan kepada pasien.

Menurut penelitian yang dilakukan oleh Gannika \& Buanasasi (2019); Zakiyah et al., (2020) bahwa gaya kepemimpinan kepala ruangan dengan kinerja perawat di ruang rawat inap RSU GMIM Pancaran Kasih Manado, didapat nilai signifikan sebesar 1,000 (p>0,05), hal ini menunjukan bahwa tidak adanya hubungan yang signifikan antara 
gaya kepemimpinan kepala ruangan dengan kinerja perawat.Hasil penelitian dapat dikatakan bahwa gaya kepemimpinan kepala ruangan tidak bisa dipastikan, karena setiap kepala ruangan atau pemimpin memiliki cara yang berbeda untuk untuk mengatur, dan mengarahkan bawahannya.

\section{SIMPULAN}

Gaya kepemimpinan demokratis yang sekarang sedang berjalan di RSU dr Moedjito Dwidjosiswojo dan dengan gaya kepemimpinan demokratis dapat menjadikan karyawan memepertahankan kedisiplinan. Terbukti dengan lama masa kerja lebih dari tiga tahun tetap disiplin dalam jam datang kerja.

\section{SARAN}

Berdasarkan hasil survei tersebut bahwa gaya kepemimpinan demokratis bisa dijalankan dalam memimpin rumah sakit. Dan lebih memperhatikan variable yang lain terkait pendukung kedisiplinan karyawan.

Disiplin kerja karyawan tidak hanya dipengaruhi oleh gaya kepemimpinan , terdapat beberapa beberapa indikator lain yang mempengaruhinya, salah satunya adalah keadilan perusahaan.

Survei ini dapat digunakan sebagai acuan bagi peneliti yang akan datang untuk mengembangkan ilmu serta teori Manajemen Sumber Daya Manusia (MSDM) dengan mempertimbangkan variabel-variabel lain diluar variabel yang ada dalam survei ini, misalnya besar kecilnya pemberian kompensasi, ada tidaknya aturan yang pasti yang dijadikan pegangan, dan sebagainya.

\section{DAFTAR PUSTAKA}

Amalia, A. W., Allorante, A. I., \& Nara, N. (2016). Gaya Kepemimpinan Direktur Rumah Sakit Umum Daerah (Rsud) Sayang Rakyat Provinsi Sulawesi Selatan. JAKPP (Jurnal Analisis Kebijakan \& Pelayanan Publik), 2(2), 1-7. https://doi.org/https://doi.org/10.31947/jakpp.v2i2.2682

Gannika, L., \& Buanasasi, A. (2019). Hubungan Gaya Kepemimpinan Kepala Ruangan dengan Kinerja Perawat di Ruang Rawat Inap Rumah Sakit GMIM Pancaran Kasih Manado. Jurnal Keperawatan, 7(1), 1-8. https://ejournal.unsrat.ac.id/index.php/jkp/article/view/25216

Kurniawan, Y. F. (2018). Pengaruh Gaya Kepemimpinan Demokratis terhadap Kinerja Karyawan di CV Anugerah Jaya. Jurnal Agora, 6(2), 1-6. http://publication.petra.ac.id/index.php/manajemen-bisnis/article/view/7794

Marques, P. M. S., Berkanis, A., \& Thresna, F. (2021). Pengaruh Gaya Kepemimpinan Kepala Ruangan terhadap Kepuasan Kerja Perawat di Hospital Referal Raeao Oe-Cusse Timor-Leste [Universitas Citra Bangsa]. http://repository.ucb.ac.id/755/1/Skripsi-Patricio M.S.Marques-161111037.pdf

Mugianti, S. (2016). Manajemen dan Kepemimpinan dalam Praktek Keperawatan. Journal of Materials Processing Technology, 1(1), 1-200. http://dx.doi.org/10.1016/j.cirp.2016.06.001\%0Ahttp://dx.doi.org/10.1016/j.powte c.2016.12.055\%0Ahttps://doi.org/10.1016/j.ijfatigue.2019.02.006\%0Ahttps://doi. org/10.1016/j.matlet.2019.04.024\%0Ahttps://doi.org/10.1016/j.matlet.2019.12725 2\%0Ahttp://dx.doi.o 
Pratama, I. G. P. A., \& Zuriana, Z. (2018). Pengaruh Gaya Kepemimpinan Demokratis dan Prestasi Kerja Karyawan terhadap Loyalitas Karyawan pada PT. Tunas Dwipa Matra (Cabang Antasari). Insitut Informatika dan Bisnis Darmajaya

Rumaisha, H. R., Surhatiningsih, S., \& Kuswanto, K. (2019). HUubngan Gaya Kepemimpinan dan Karakteristik Pemimpin dengan Kinerja Perawat di Puskesmas Takeran Kecamatan Takeran [Stikes Bhakti HUsada Mulia Madiun]. http://repository.stikes-bhm.ac.id/671/1/1.pdf

Tilman, R. J. D. J. A., Fouk, M. F. W. A., \& Rohi, E. D. R. (2019). Kinerja Perawat dalam Melaksanakan Asuhan Keperawatan di Ruang UGD Rumah Sakit Nasional Guido Valadares Dili, Timor-Leste. Jurnal Sahabat Keperawatan, 1(01), 28-40. https://doi.org/10.32938/jsk.v1i01.88

Zakiyah, N., Asrinawaty, A., \& Aquarista, M. F. (2020). Faktor-Faktor yang Berhubungan dengan Kinerja Perawat di Ruang Rawat Inap RSUD dr. H. Moch Ansari Saleh Banjarmasin Tahun 2020 [Universitas Islam Kalimantan]. In Repository Universitas Islam Kalimantan. http://eprints.uniska-bjm.ac.id/2656/ 